\title{
HILL v. SOUTH ALBERTA LAND REGISTRATION DISTRICT: THE LIMITATION PERIOD FOR BRINGING AN ACTION TO RECOVER DAMAGES FROM THE ASSURANCE FUND
}

\section{W.H. HURLBURT*}

One question raised in Hill v. South Alberta Land Registration District' is the effect of section 168 of the Land Titles Act, which imposes a limitation period on making claims against the assurance fund that is maintained, notionally or in fact, under the Land Titles Act. $^{2}$

In $1977, O^{3}$ was the registered owner of a house and lot subject to some encumbrances. In that year, a forged transfer in favour of $A^{4}$ was registered, followed immediately by a mortgage duly executed by $\mathrm{A}$ in favour of $\mathrm{B},{ }^{5}$ the two documents having been simultaneously deposited for registration by B's lawyer in accordance with usual conveyancing practice. B's lawyer then paid out the encumbrances from the mortgage proceeds and paid the balance of the proceeds according to what he thought were O's instructions, though it appears that these instructions were invalid. O did not receive the money.

At that point, title was registered in A's name, subject only to B's mortgage. Both A and $B$ acted in good faith and in the belief that they were dealing with $O$. $O$ had no knowledge of the registrations. $\mathrm{O}$ and her husband continued in residence in the property under an arrangement made by the husband with $A$. Then, the mortgage fell into arrears, contrary to the husband's agreement with A, and B took foreclosure proceedings on the mortgage. O counterclaimed against $\mathrm{A}, \mathrm{B}$, her husband and others, claiming that the mortgage was part of a fraudulent conspiracy. (Title to the property had been retransferred to $O$ under an agreement between $O$ 's husband and $A$.)

In the mortgage action, ${ }^{6}$ the trial judge held that only the husband was guilty of fraud. However, he held that the mortgage was invalid on the grounds that the forged transfer from $O$ to $A$ had not been registered at the time when $B$ obtained the mortgage from $A$, so that $B$ relied on the forged transfer and not on the register, which showed $O$ as the owner. The Court of Appeal reversed the decision. ${ }^{7}$ Mr. Justice Stevenson, speaking for the court, said that

a forged transfer gives root to a good title and (subject to exceptions not relevant) a mortgagee is protected if it deals with the holder of that title

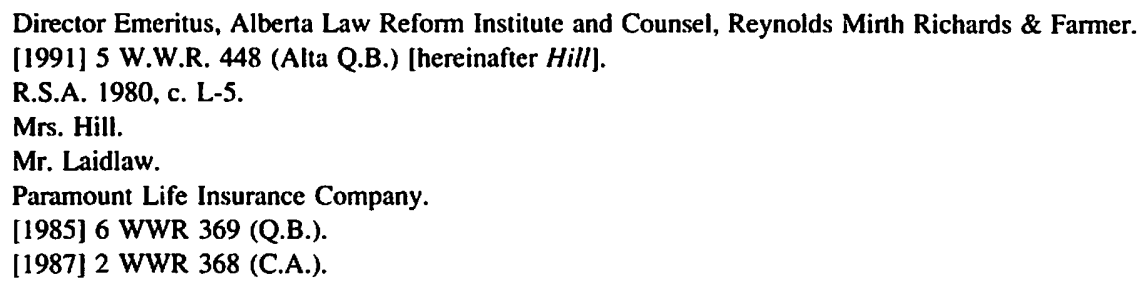


and that

it is not necessary that a proposed encumbrancer physically examine the register, as he may instruct the registrar to register the document only if the documents contemporaneously registered produce a valid title effective immediately prior to the registration of the encumbrance. ${ }^{k}$

Following the Court of Appeal's decision, the foreclosure proceedings were completed and $O$ had to vacate the property.

$\mathrm{O}$ then claimed damages from the assurance fund. Counsel for the Registrar appears to have conceded that $O$ had had a valid claim against the fund but raised as a defence the limitation provision, section 168 of the Land Titles Act. The issue revolves around two sections, 158 and 168 , which are as follows:

158 Any person

(a) who sustains loss or damage through an omission, mistake or misfeasance of a Registrar or an official in his office in the execution of his duties, or

(b) who is deprived of any land or encumbrance or of an estate or interest therein

(i) through the bringing of it under this Act,

(ii) by the registration of another person as owner of the land or encumbrance, or

(iii) by an error, omission or misdescription in a certificale of title,

and who by this Act is barred from bringing an action for the recovery of the land or encumbrance or interest therein.

may bring an action against the Registrar of the district in which the land is situated for the recovery of damages.

168(1) No action for damages under this Act shall be brought against the Registrar

(a) by reason of the deprivation of land unless it is brought within 6 years from the date when the deprivation took place,...

Counsel for the Registrar contended that $O$ had been "deprived" of her land in 1977, when the forged transfer and mortgage were registered, and that the action against the Registrar, which was not commenced until after the Court of Appeal delivered its December 1986 judgment, was therefore out of time. Alternatively, counsel contended 
that $\mathrm{O}$ had discovered the deprivation more than six years before bringing action, so that if the period under section 168 runs from the discovery of the deprivation and not from its occurrence, the action was still out of time.

Madam Justice Rawlins held that $O$ had not been deprived of the land until she was dispossessed in 1987, relying upon a definition of the expression "be deprived of his property" that appears in Black's Law Dictionary: "Denotes a taking altogether, a seizure, a direct appropriation, dispossession of the owner." The limitation period, therefore, did not begin to run until 1987, and the action was brought in time. She said

If I accede to the position of the defendant and choose deprivation to have occurred when the first fraudulent transfer was made which transfer was subsequently re-registered in Mrs. Hill's name, effectively she had suffered little damage. She was unaware that such dealings with her land had actually taken place, and she had continued uninterrupted enjoyment of her land. Had her husband continued to make the mortgage payments to Paramount and not defaulted, I fail to see how any deprivation had taken place by reason of the placement of the mortgage."

Justice required that $\mathrm{O}$ succeed. She had clearly suffered loss from the workings of the land registration system and injustice should be compensated from the fund provided for that purpose by users of the system, presumably including herself. The result did not offend limitations policy. $O$ had not slept on her rights (and indeed had vigorously, if, in the result, mistakenly, asserted them). In the nature of things the Registrar must have known about the registration of the forged transfer and the mortgage at an early date, and there is nothing to suggest that the early commencement of a protective action against the Registrar would have helped the Registrar to defend the action or that the delay in bringing action caused any prejudice to the Registrar.

Land registration policy also required that $O$ recover from the assurance fund. The purpose of land registration is to make conveyancing easy, quick, cheap and safe. But a land registration system that achieves that purpose, however efficient it is, necessarily causes loss to some users, whether by giving scope to the fraud of individuals or through error by users or administrators. ${ }^{10}$ The principal purpose of the assurance fund is to satisfy users that they can rely on the system because they will be compensated for any system malfunction that occurs. The secondary purpose, without which the first purpose cannot be achieved, is to effect the compensation. Both purposes require that the fund be reasonably accessible to persons with valid claims. If O's claim had been denied, the assurance fund would have failed to achieve its purposes.

However, the judge's interpretation of section 168 was robust and might not be accepted by an appellate court, which might conclude that a person who has lost her title altogether or has had it subjected to a mortgage has been "deprived" of land within the meaning of sections 158 and 168 , so as to start the limitation period running. In

10. There is no reason to think that land registration causes more losses than does the common law system of land ownership and conveyancing. However, it causes losses to different people. 
McWhorter v. Reg., North Alta. Land Registration District, " for example, the Court of Appeal used the word "deprivation" to cover the unjustified cancellation of a certificate of title to minerals as well as surface in tax sale proceedings, and it dealt with the case as if the claim against the assurance fund was for "deprivation" of the minerals. The court did not directly address the question whether something happening on the register amounts to deprivation, and the decision is in the form of a memorandum of judgment and is therefore not entitled to full precedential value, but it does suggest a possible appellate approach that would characterize the loss of ownership rights through entries in the register as "deprivation" of those rights.

Further, the interpretation might itself cause difficulties under different circumstances. Suppose, for example, that $\mathrm{O}$, after the Court of Appeal decision, had sold the property or refinanced it with another mortgage (thus retaining ownership and possession), or suppose that instead of being an owner she had been a mortgagee and had lost the mortgage through the registration of a forged discharge. In any of these events, she would not have been deprived of property by a "seizure, a direct appropriation, or by dispossession" and thus would not, under the interpretation adopted in the Hill case, have had a claim against the assurance fund under section 158(b), which depends upon an owner having been "deprived." It is true that in any of those hypothetical cases, the victim might claim instead under section 158(a) on the basis of an alleged mistake by the Registrar, but there would then be an argument about whether the Registrar makes a "mistake" by accepting a forged document. In one sense there is clearly a mistake, as a forged signature has been accepted as being valid. In another sense, the Registrar does not make a "mistake" because it is their duty to accept documents if certain prescribed formalities have been observed. It should also be noted that the limitation period for a claim based on Registrar's error is also six years, so that the relief against the limitation period given by the judgment in the Hill case would not be available in claims under section 158(a).

As noted above, counsel for the Registrar had put forward an alternative argument based on the premise that a "discoverability" rule applied to section 168. In the McWhorter case, the chambers judge held ${ }^{12}$ that such a rule did apply, relying on Kamloops v. Nielsen ${ }^{13}$ and Central Trust Co. v. Rafuse, ${ }^{14}$ though even after applying it he found that the claimant was out of time. On appeal, the Court of Appeal said that it was not agreeing or disagreeing with the chambers judge's view that the discoverability rule applied. It said, without giving reasons, that that issue was not reached in the case. There is therefore an unresolved issue as to whether the limitation period in section 168 starts with the events that confer a cause of action on a claimant or whether it starts, in the words of Le Dain J. in the Rafuse case, "when the material facts on which [the cause of action] is based have been discovered or ought to have been discovered by the plaintiff by the exercise of reasonable diligence." 
The Alberta Law Reform Institute has under consideration the Model Land Recording and Registration Act, ${ }^{15}$ which, if adopted, would replace the Land Titles Act. Section 7.1 of the Model Act, broadly paraphrased, says that a person who suffers loss through a malfunction of the land registration system is entitled to be compensated for the loss sustained. Section 7.3 goes on:

The person ceases to be entitled to compensation unless, before the expiration of two years after he knows or ought to know of the loss sustained or within such further time as is agreed to by the Registrar General, he either

(a) enters into an agreement with the Registrar General providing for the payment of compensation, or commences an action for compensation in the Court.

It will be seen that this section provides a limitation period of 2 years from actual or imputed discovery. That seemed to the Joint Committee which prepared the Model Act to be fair.

Would a discovery, or discoverability, rule have protected $\mathrm{O}$ in the Hill case? It appears that counsel for the Registrar contended that it would not. The reported judgment does not outline his argument. Presumably it was that once $O$ knew that title had been registered in A's name and that the mortgage had been registered in B's name, the discoverability rule would have been satisfied and the limitation period would begin to run.

However, I think it likely that a discoverability rule would have protected $O$. The fact that the mortgage was taken in good faith was a material fact and one that was an essential component of her loss. Discovery of the registration of the forged transfer plus discovery of the registration of the mortgage was not discovery of all the material facts. Until the trial judge gave judgment, $O$ was litigating on the basis that she had a right to have the mortgage set aside on the grounds of fraud. It was only when that judgment was given that she could be said to have "discovered" that the mortgage was taken in good faith. It can therefore be argued that until the trial judgment was given, the Rafuse rule would have protected her insofar as actual "discovery" was concerned. Further, it would be harsh to say that $O$ "ought to have discovered" that the mortgage had been taken in good faith when she was alleging, presumably in good faith and on the basis of legal advice, that it had not.

The Model Act test would be more protective of $O$ than would the Rafuse test, as it requires discovery of the "loss," and not merely of the material facts that lead to the

15. See Joint Committee on Land Titles, Renotating the Foundation: Proposals for a Model Land Recording and Registration Act for the Provinces and Territories of Canada, July 1990, and Alberta Law Reform Institute, Towards a New Alberta Land Titles Act, Report for Discussion No. 8, August 1990. 
conclusion that in law a loss has occurred. As noted above, $O$ could not be said to have discovered the last material fact until the trial judge gave judgment. When the trial judge did give judgment, it was that the mortgage was invalid, and it would be harsh to say that a successful plaintiff exercising reasonable diligence ought to discover that the judgment in their favour is wrong. A good case can be made for the proposition that $\mathrm{O}$ did not "discover" her loss until the Court of Appeal's judgment told her that she had lost the case.

The result of this discussion is that the law under section 168 is not clear. Until something is done, prudence suggests that where any possible outcome of litigation would mean the loss or subordination of an interest in land due to Registrar's error or other system malfunction, the Registrar should be joined as a party to the litigation or a separate action should be started within the limitation period and kept on foot until the primary litigation is disposed of. Adoption of the Model Act would help to clarify the legal situation, and it might be a sufficient remedy: if it were only when knowledge of a "loss" is acquired or imputed that the time starts to run, the court would have a good deal of flexibility to see, on the one hand, that claimants are not allowed to sleep on their rights, but also to see, on the other hand, that the limitation provision does not defeat the purposes of the Land Titles Act compensation scheme.

The approach of the Model Act to the limitation provision is consistent with its approach to the compensation system. The land registration system is in the public interest because it improves efficiency in land dealings, but it inevitably causes loss to a small number of users. The compensation system is in the public interest because, at the expense of users, it encourages users to have confidence in the land registration system and to refrain from taking expensive and time-consuming steps to protect themselves. The compensation system should satisfy legitimate claims without undue delay and nonfunctional barriers should not be erected around it. A limitation provision is necessary, but it should be designed to avoid depriving victims of their recourse without good reason. 